\title{
Ichnology of the Early Cambrian Tal Group, Mussoorie Syncline, Lesser Himalaya, India
}

\author{
Meera Tiwari*, S K Parcha, Rajita Shukla and Harshita Joshi \\ Wadia Institute of Himalayan Geology, 33, General Mahadeo Singh Road, Dehradun 248 001, India. \\ *Corresponding author.e-mail: mtiwari@wihg.res.in, meeratiwari2@gmail.com
}

The Lesser Himalayan sequence is considered as one of the best developed sections of Cambrian successions, exposed in five different synclines. Mussoorie Syncline, being one of the five synclines, exposes the Cambrian Tal Group. This paper describes nine ichnotaxa, viz., Dimorphichnus isp., ?Diplichnites isp., Monomorphichnus isp., Nereites isp., Palaeopasichnus isp., Palaeophycus isp., Planolites montanus, Planolites isp., Skolithos isp., Treptichnus isp. from the Dhaulagiri Formation of the Tal Group. A detailed analysis of the ichnofossils indicates that the entire succession of Tal Group reflects shallow marine conditions in general and Mussoorie Syncline in particular. The above ichnofossil assemblage along with earlier ichnofossils and other faunal occurrences substantiates the assignment of Early Cambrian age to the Dhaulagiri Formation.

\section{Introduction}

The Mussoorie Syncline is the most important area for understanding the Early Cambrian paleobiology of the Lesser Himalaya. The Tal Group of Mussoorie Syncline provides numerous Ediacaran to Cambrian transitional sections. Due to less susceptibility to taphonomic bias, particularly in areas dominated by siliciclastic sediments, trace fossils are considered as important palaeoenvironmental indicators and may trace the evolution of lifestyles of marine benthic organisms (Conway Morris 1993, 1998; Erwin et al. 1997; Droser et al. 1999; Jensen et al. 2000). A number of researchers described trace fossils including trilobite traces and body fossils from the Tal Group of Mussoorie Syncline (Banerjee and Narain 1976; Kumar et al. 1983; Singh and Rai 1983; Bhargava 1984; Singh et al. 1984; Rai 1987; Tiwari and Parcha 2006). Present work has yielded new ichnological data from the B member of Dhaulagiri (Upper Tal) Formation and the purpose of this paper is to describe and discuss the implications of trace fossils from this part of the Mussoorie Syncline.

\section{Geology of the area}

The topmost lithostratigraphic unit of the Krol Belt of Lesser Himalaya is represented by the Tal Group. Medlicott (1864) identified it for the first time in Nilkanth area of Garhwal Syncline. Subsequently, several other researchers proposed different schemes of classification (Middlemiss 1887; Auden 1934; Bhargava 1972; Shanker 1973, 1975; Valdiya 1975; Shanker et al. 1993). In the present work, the scheme proposed by Shanker et al. (1993) is followed. In Mussoorie Syncline, the Tal Group conformably overlies the Kauriala Formation of the Krol Group and is in turn overlain unconformably by the Shell Limestone Formation. The Tal Group is divisible into two formations, viz., Deo-ka-Tibba (Lower Tal) and Dhaulagiri (Upper Tal) (table 1). The Deo-ka-Tibba Formation consists of chert,

Keywords. Trace fossils; Dhaulagiri Formation; Tal Group; Early Cambrian; Lesser Himalaya; India. 
Table 1. Generalised stratigraphic succession of the area based on Shanker et al. (1993).

\begin{tabular}{|c|c|c|c|}
\hline Group & Formation & Member & Description \\
\hline \multirow{10}{*}{ Tal } & \multirow{5}{*}{ (Dhaulagiri (Upper Tal) } & $(\mathrm{E}$ & Quartz-arenite, shale and siltstone \\
\hline & & $\mathrm{D}$ & Algal limestone and siltstone \\
\hline & & $\mathrm{C}$ & Felspathic quartz-arenite \\
\hline & & $\mathrm{B}$ & Black shale and quartz-arenite \\
\hline & & A & Quartz-arenite \\
\hline & \multirow{4}{*}{ ( Deo-ka-Tibba (Lower Tal) } & Calcareous & Calcareous, ferruginous siltstone, siliceous limestone \\
\hline & & Arenaceous & Banded siltstone \\
\hline & & Argillaceous & Black shale with calcareous bands \\
\hline & & Chert & Bedded chert with black shale and rock phosphate \\
\hline & \multirow[t]{2}{*}{ (Kauriala (Upper Krol) } & & Argillaceous limestone with interbedded calcareous shale \\
\hline \multirow{3}{*}{ Krol } & & & Dolomitic limestone and shale bluish grey limestone \\
\hline & Jarashi (Middle Krol) & & $\begin{array}{l}\text { Red to purple coloured shales with some intercalated } \\
\text { green shale layers }\end{array}$ \\
\hline & Mahi (Lower Krol) & & $\begin{array}{l}\text { Grey to greenish-grey calcareous shales to siltstones and } \\
\text { argillaceous limestones }\end{array}$ \\
\hline \multirow{3}{*}{ Baliana } & Chambaghat & & Sandstone, orthoquartzite and lenses of sandy units \\
\hline & S Infrakrol & & Dark carbonaceous shales/siltstones \\
\hline & Z Blaini & & $\begin{array}{l}\text { Conglomerate diamictite grading upward into } \\
\text { carbonate bed }\end{array}$ \\
\hline
\end{tabular}

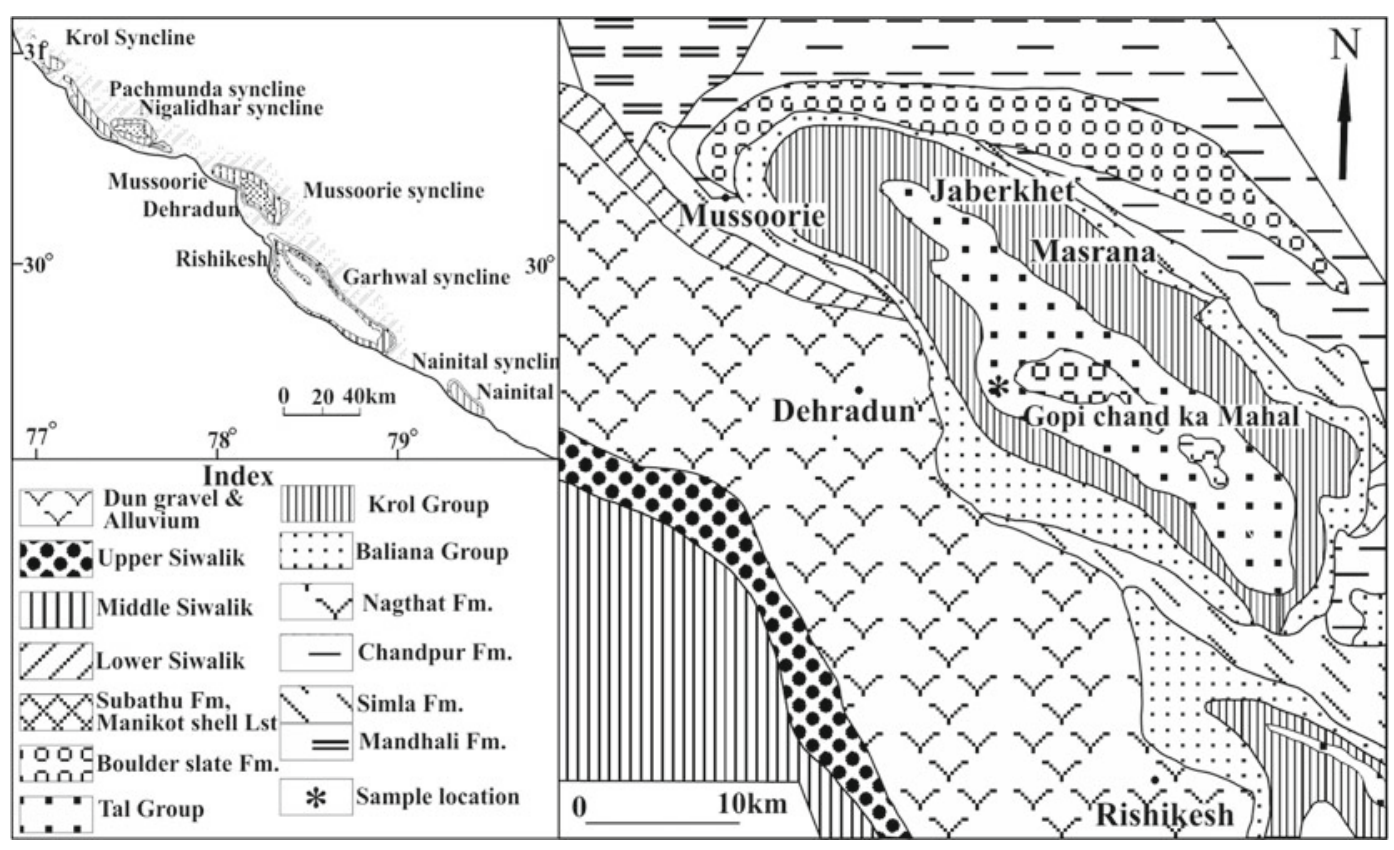

Figure 1. Geological map of the area showing fossil locality.

black shale, siltstone and siliceous limestone and is subdivided into four informal members, viz., Chert, Argillaceous, Arenaceous and Calcareous members. The Dhaulagiri Formation consists of quartz arenite, with minor felspathic arenite, shale, siltstone and limestone. It is divisible into five informal members, viz., A, B, C, D and E (Bhargava 1972; Shanker 1973, 1989; Shanker et al. 1993). The present fossil assemblage occurs within member B of the Dhaulagiri Formation. Trace fossils were collected from a well-bedded section of greyish-black siltstone with minor intercalation of silty shale layers, occurring below thin quartz arenite, exposed along the Maldeota-Dhaulagiri road section, approximately $4 \mathrm{~km}$ from Dhaulagiri $\left(30^{\circ} 20^{\prime} 39.5^{\prime \prime}: 78^{\circ} 09^{\prime} 39.1^{\prime \prime}\right)$ (figures 1 and 2). 


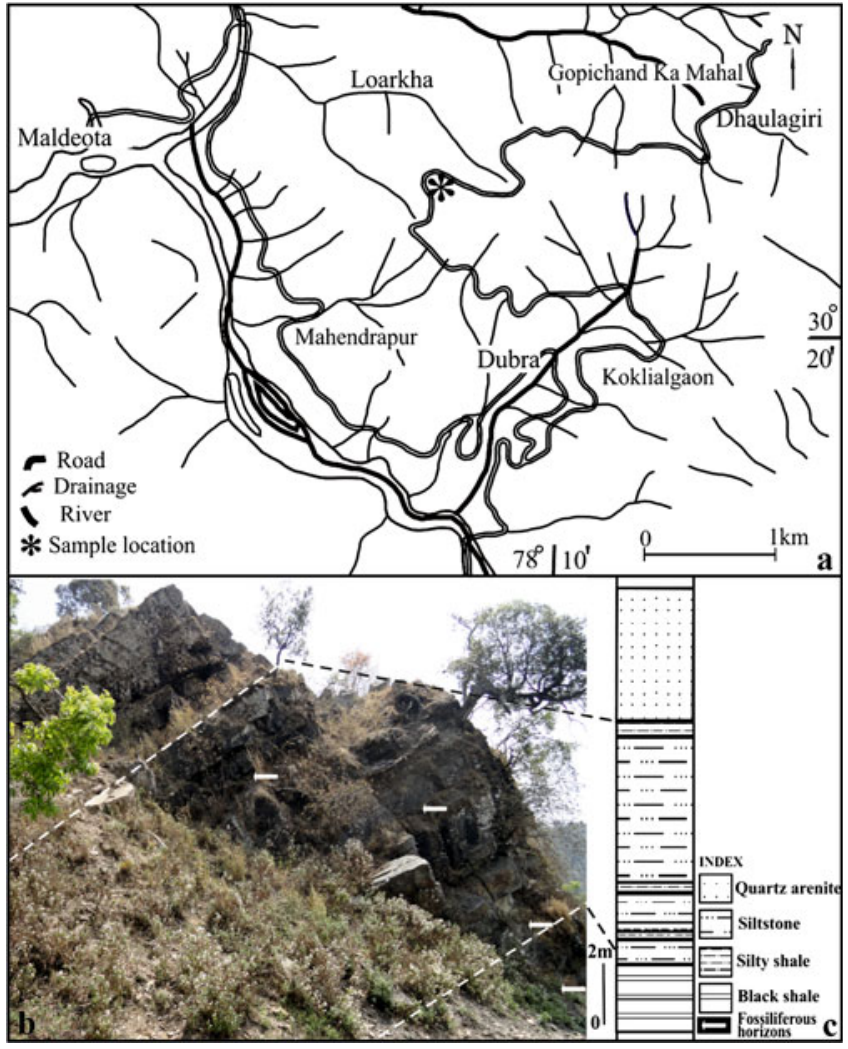

Figure 2. (a) Road map of the area. (b) Field photograph of the area, arrows point to sample location. (c) Litholog of the area showing sample location.

\section{Trace fossil occurrences}

In Mussoorie Syncline, the Arenaceous member of Deo-ka-Tibba (Lower Tal) Formation has yielded considerable number of trace fossils. Banerjee and Narain (1976) were the first to report trace fossil Aulichnites from the Arenaceous member. The reported trace fossils mainly belong to Skolithos and Cruziana ichnofacies with an abundance of arthropod traces like Diplichnites, Merostomichnites, Dimorphichnus, Monomorphichnus, Protichnites and Tasmanadia (Kumar et al. 1983; Singh and Rai 1983; Bhargava 1984; Singh et al. 1984; Rai 1987). In contrast, there are limited reports of trace fossil from the Dhaulagiri Formation. The published reports include trace fossils Paleophycus and Skolithos along with arthropod traces of Lower Cambrian affinity from member A of Dhaulagiri Formation (Bhargava 1984; Rai 1987; Bhargava et al. 1998). The lowermost part of Dhaulagiri Formation on the Mussoorie-Dhanaulti road section has yielded Early Cambrian trace fossils similar to those of the Arenaceous member of the Deoka-Tibba Formation. The reported trace fossils are Monomorphichnus isp., Dimorphichnus isp., Diplichnites isp. A, Planolites isp., Skolithos isp., Merostomichnites isp., ?Neonereites isp., along with various scratch marks and burrows (Tiwari and Parcha 2006). The member B of Dhaulagiri Formation contains nine new ichnotaxa (this paper) identified as Dimorphichnus isp., ?Diplichnites isp., Monomorphichnus isp., Nereites isp., Palaeopasichnus isp., Palaeophycus isp., Planolites montanus, Planolites isp., Skolithos isp., Treptichnus isp. along with some meandering trails.

The ichnogenera described here are housed in the repository section of the Wadia Institute of Himalayan Geology Museum, Dehradun, India and bear the catalogue numbers WIHG/A/1921WIHG/A/1935.

\section{Systematic ichnology}

Ichnogenus Dimorphichnus Seilacher (1955)

Dimorphichnus isp.

Figure 3(h)

Material: One specimen is preserved as a hyporelief.

Repository: WIHG/A/1925.

Description: Two sets of asymmetrical, small, unbranched, wedge and rib-shaped markings of varying size. Each individual wedge is set $3-6 \mathrm{~mm}$ apart from the other; length of the individual markings varies from $6-10 \mathrm{~mm}$ and width from 2-4 mm. Some of the markings are shifted towards the other side, suggesting changes in the movement of the animal. The infilled material in the markings is same as the host material.

Remarks: The present specimen is comparable to the ichnogenus Dimorphichnus due to its curved and sub-parallel ridges. The specimen differs from Dimorphichnus isp. reported from the Cambrian sequences of the Tethyan Himalayan region, in nature and pattern of wedge markings (Shah and Sudan 1983; Bhargava and Bassi 1988; Parcha 1998; Parcha and Singh 2010; Parcha and Pandey 2011). It equally differs from the ichnospecies Dimorphichnus described by Singh and Rai (1983) and by Tiwari and Parcha (2006) from the Lesser Himalaya and also with the species described by Kumar and Pandey (2010) from Rajasthan. This ichnogenus is also known from the Lower Cambrian successions of Salt Range (Seilacher 1955, 1967).

Ichnogenus Diplichnites Dawson (1873)

?Diplichnites isp.

Figure 3(g)

Material: Specimen preserved as hyporelief.

Repository: WIHG/A/1927.

Description: Well-preserved markings in a single row; markings curved and parallel to each other. The individual length of the markings varies from $8-13 \mathrm{~mm}$ and width from $2-3 \mathrm{~mm}$. The distance between two parallel markings is $3-4 \mathrm{~mm}$. 

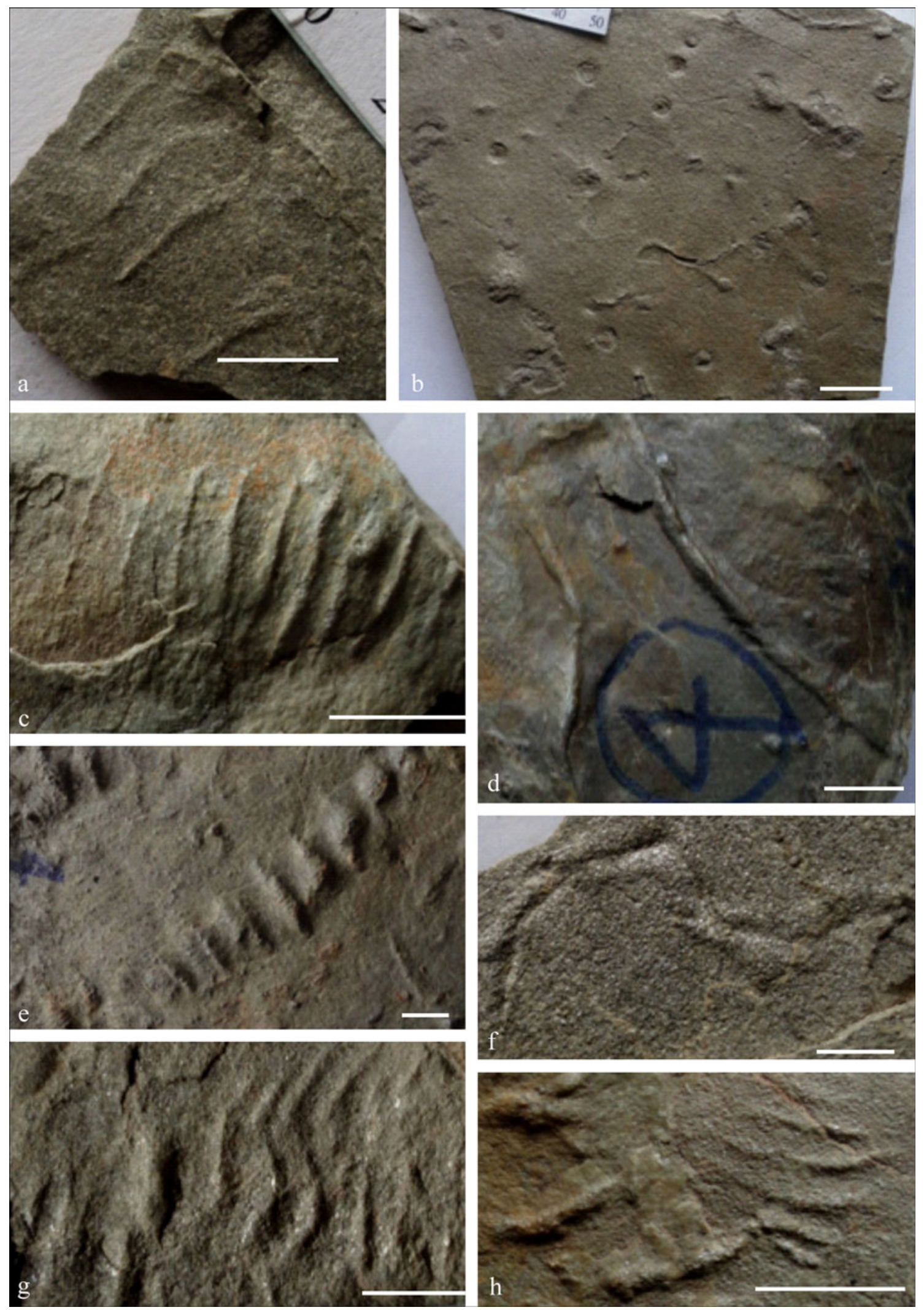

Figure 3. (a, c) Monomorphichnus isp., (b) Skolithos isp., (d) Planolites isp., (e) Palaeopasichnus isp., (f) Treptichnus isp., (g) ?Diplichnites isp., and (h) Dimorphichnus isp. 
The markings indicate crawling activity of an arthropod on the soft sediments.

Remarks: The present specimen is grouped under the ichnogenus Diplichnites because of the presence of serial markings and curved nature. The specimen differs with Diplichnites ichnospecies described from the Lesser, Spiti and Zanskar Himalaya in the absence of two parallel, equally spaced rows (Parcha 1998; Tiwari and Parcha 2006; Parcha and Singh 2010; Parcha and Pandey 2011).

Ichnogenus Monomorphichnus Crimes (1970) Monomorphichnus isp.

Figure 3(a, c)

Material: Two slabs of coarse-grained sandstone showing two specimens on the sole of the bed. The specimens are preserved as positive relief.

Repository: WIHG/A/1929, 1930.

Description: Series of isolated, slightly curved ridges repeated laterally, moderately spaced from each other; ridges vary in length from 8-10 mm, in width from $1.5-2 \mathrm{~mm}$ and are $2-3 \mathrm{~mm}$ apart from each other.

Remarks: The present specimen differs from Monomorphichnus monolinearis described from Kashmir by Shah and Sudan (1983) and with the species of Monomorphichnus described from Zanskar (Parcha 1998; Parcha and Singh 2010) and Spiti (Parcha and Pandey 2011) in the nature and pattern of the ridges. The present specimens equally differ from Monomorphichnus species described from member A of the Dhaulagiri Formation of the Lesser Himalaya (Tiwari and Parcha 2006), Monomorphicnus lineatus described from Calcareous member of Deo-ka-Tibba and A, B members of Dhaulagiri Formation in Nigalidhar Synform (Desai et al. 2010) and from Monomorphichnus isp. described from Rajasthan, in nature, size and pattern of ridges (Kumar and Pandey 2010). The ichnogenus Monomorphichnus is recorded from almost all the Cambrian successions of the Tethyan Himalayan regions.

Ichnogenus Nereites Macleay (1839)

Nereites isp.

Figure 4(f)

Repository: WIHG/A/1923.

Material: One specimen preserved in siltstone as positive relief.

Description: Simple, irregular, meandering trail with numerous irregular pellets; meanders of variable dimensions and touching the neighbouring segments. The total length of the trail is $35 \mathrm{~mm}$; length of the individual lobe varies from $6-8 \mathrm{~mm}$ whereas the width varies from 3-4 mm.

Remarks: The specimen shows close similarity with the ichnogenus Nereites in its meandering pattern of the trail. The present form differs from the Nereites isp. described from the Spiti Basin in having a single row of claw markings as compared to two rows in the latter (Parcha and Pandey 2011).

Ichnogenus Palaeopasichnus Palij (1976)

Palaeopasichnus isp.

Figure 3(e)

Material: One specimen preserved in coarsegrained sandstone as positive relief.

Repository: WIHG/A/1931.

Description: Bars arranged in a single row; bars closely spaced, wide in the middle and elongated towards the margins. The number of bars in a row is 12. The total length of the row is $85 \mathrm{~mm}$; length of individual bar varies from $6-15 \mathrm{~mm}$ and width varies from 3-7 $\mathrm{mm}$; the distance between two successive bars varies from $4-6 \mathrm{~mm}$.

Remarks: The present specimen shows close similarity with the ichnogenus Palaeopasichnus in nature and pattern of bars. The specimen differs from Palaeopasichnus from the Cambrian of Spiti Basin in its unbranching nature (Parcha and Pandey 2011).

Ichnogenus Palaeophycus Hall (1847)

Palaeophycus isp.

Figure 4(b)

Material: One specimen preserved in coarsegrained sandstone.

Repository: WIHG/A/1928.

Description: Smooth and curved bulbous burrow with faintly preserved constrictions. The length of the burrow is $12 \mathrm{~mm}$ and the maximum width is $3 \mathrm{~mm}$. Infilling material of the burrow is same as that of the host rock.

Remarks: The specimen differs with Palaeophycus tubularis Hall (1847) and that described by Desai et al. (2010) from the Tal Group in the length-width ratio. The specimen differs with the form described from Spiti in the absence of short ridges on the surface (Parcha and Pandey 2011). The specimen also differs with Palaeophycus bolbitermilus described by Kim et al. (2000) in the absence of terminal bulbs.

Ichnogenus Planolites Nicholson (1873)

Planolites montanus Richter (1973)

Figure 4(e)

Material: Two well-preserved specimens preserved as hyporelief.

Repository: WIHG/A/1935.

Description: Simple, horizontal, unbranched smooth burrows varying from $4-5 \mathrm{~mm}$ in diameter and up to $60 \mathrm{~mm}$ in length. The sediment fill of the burrow is of the same material in which they are preserved.

Remarks: The present specimen shows close resemblance in morphology to Planolites montanus 

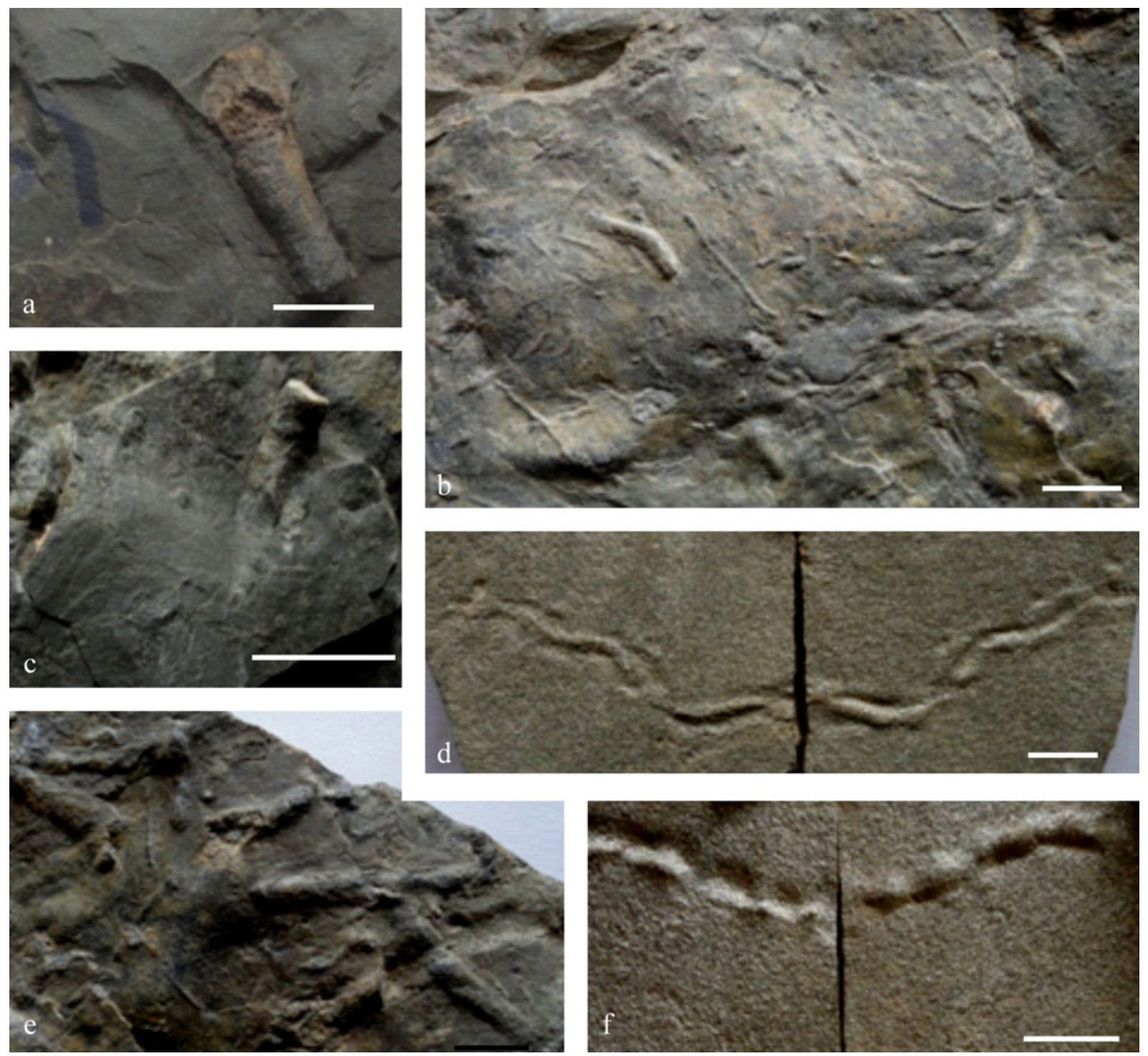

Figure 4. (a, c) Planolites isp., (b) Palaeophycus isp., (d) winding trails, (e) Planolites montanus and (f) Nereites isp.

Richter described by Metz (1995), hence assigned to the same ichnospecies.

Ichnogenus Planolites Nicholson (1873)

Planolites isp.

Figure 4(a, c)

Material: Two slabs of coarse-grained sandstone containing five well-preserved specimens preserved as hyporelief.

Repository: WIHG/A/1933-1934.

Description: Straight to slightly curved, horizontal, short, smooth burrows of varying shapes and diameters, lacking wall lining. The individual length of the burrow varies from $20-35 \mathrm{~mm}$, whereas, the width varies from 5-8 $\mathrm{mm}$. Burrows are slightly expanded at one end. The sediment filling of the burrows is of the same material as the host rock.
Remarks: The present specimens closely resemble ichnogenus Planolites in their unbranched nature. The present form differs with the Planolites described from the Cambrian of Zanskar Valley (Parcha and Singh 2010) and Spiti in the absence of closely spaced striae (Parcha and Pandey 2011). It shows some affinity with the species described from the A member of Dhaulagiri Formation but differs with it in the nature of burrow (Tiwari and Parcha 2006). It is often difficult to make a distinction between morphologically similar ichnogenera Planolites and Palaeophycus, apart from the nonbranching nature of the burrow. However, the specimen differs with all the known ichnospecies of Planolites in nature and pattern of burrow. It is the most common ichnogenus found in the Lesser and Tethyan Himalayan regions. 
Ichnogenus Skolithos Haldemann (1840)

Skolithos isp.

Figure 3(b)

Material: The specimens are preserved on three slabs of micaceous sandstone.

Repository: WIHG/A/1922-1926.

Description: Small, straight, unbranched, vertical burrows occurring as circular to sub-circular bodies on the surface of the bedding plane; diameter of the burrows ranges from $2-7 \mathrm{~mm}$, the inner circle of the burrow ranges from $2-5 \mathrm{~mm}$; space between burrows is wide; burrow is filled with same sediment as the host rock. Vertical section is also well-preserved.

Remarks: The present ichnospecies shows some similarity with Skolithos linearis Haldemann (1840), but differs with it in pattern and nature of burrow. Similar type of trace fossils were reported from the Dhaulagiri Formation (Tiwari and Parcha 2006). The present specimen differs from the Skolithos isp. described from Zanskar and Spiti in the absence of inner circle (Parcha and Singh 2010; Parcha and Pandey 2011). In the described specimens, slight inclination of burrow is seen in vertical section.

Ichnogenus Treptichnus Miller (1889)

Treptichnus isp.

Figure 3(f)

Material: The present specimen is preserved as epirelief.

Repository: WIHG/A/1932.

Description: Short, curved burrows having branches; the burrows vary in width from 3-6 $\mathrm{mm}$ and length from 8-18 mm. Alternating set of burrows bifurcate to give rise to branches.

Remarks: The specimen shows close resemblance with the ichnogenus Treptichnus, but differs from all known species of this genus in the nature of burrow. It shows some resemblance with Treptichnus pedum in nature and pattern of the burrow but due to poor preservation the present specimen could not be grouped with this species.

Winding Trails

Figure 4(d)

Material: The present specimen is preserved as epirelief.

Repository: WIHG/A/1924.

Description: Thin trail more or less straight, tapering at one end; the diameter of the trail ranges from $2-3 \mathrm{~mm}$ and varies in length from $20-35 \mathrm{~mm}$; the in-filled sediment is same as that of the host rock.

\section{Discussion and conclusion}

The Tal Group contains a variety of trace fossils, most of which are facies independent. The studied assemblage of trace fossils is found in the form of tracks, burrows, grooves along with scratch marks, whereas trails occur as grooves and ridges with positive epireliefs. The present ichnofossil assemblage is dominated by surface trails along with simple forms like vertical to horizontal burrows having distinct lined walls.

The detailed analysis of the earlier described trace fossils by different researchers and those from the present study area indicates that there exist two distinct levels of trace fossils, one in the Arenaceous member of the Deo-ka-Tibba Formation and the other in the A and B members of the Dhaulagiri Formation. Earlier, Rai (1987) assigned a Lower Cambrian age to the Arenaceous member of the Deo-ka-Tibba Formation, exposed in Mussoorie Syncline on the basis of ichnogenera Rusophycus, Cruziana, Skolithos, Plagiogmus and Diplichnites. A lower Cambrian age was also suggested for lower part of Dhaulagiri Formation (=Sankholi Formation) exposed in Nigalidhar Syncline (Bhargava 1984; De et al. 1994; Desai et al. 2010). Similarly, a trace fossil assemblage comprising Monomorphichnus isp., Dimorphichnus isp., Diplichnites isp. A, Planolites isp., Skolithos isp., Merostomichnites isp. and ?Neonereites isp. was reported from member A of the Dhaulagiri Formation (Tiwari and Parcha 2006), whereas, member B contains a much diverse and better preserved assemblage consisting of Nereites isp., Palaeopasichnus isp., Palaeophycus isp., Planolites montanus, Skolithos isp., Treptichnus isp., Dimorphichnus isp., ?Diplichnites isp., Monomorphichnus isp., and Planolites isp. Similar ichnogenera have also been reported from the Lower Cambrian successions of the Tethyan Himalayan sequences exposed in Parahio section of Spiti and in Zanskar basin, where the ichnofossil-bearing horizon is overlain by definite Lower Cambrian and Middle Cambrian trilobite-bearing horizons (Parcha and Singh 2010; Parcha and Pandey 2011). In Mussoorie Syncline, presence of inarticulate brachiopods from member B of the Dhaulagiri Formation further suggests Atdabanian (=Qiongzhusian/Chiungchussu) age (Early Cambrian) for the Dhaulagiri Formation (Tripathi et al. 1984). Therefore, the ichnofossil assemblage and the body fossils indicate an Early Cambrian age to the Dhaulagiri Formation.

The traces described here are interpreted to be dwelling traces made by filter feeding organisms. The traces are moderately crowded on bedding plane and are restricted to the thinly laminated sandy and silty layers only, thereby indicating substrate preference of the trace making organisms. This indicates low to moderate oxygenated conditions. The dominance of deposit feeding traces indicates presence of abundant food resources along 
with low to moderate energy and low turbidity conditions. The detailed analysis of the trace fossils indicates fluctuating energy conditions with fluxes of turbid water. The studied ichnofossils indicate shallow marine depositional conditions for the entire succession of the Dhaulagiri Formation.

\section{Acknowledgements}

The authors thank the Director, Wadia Institute of Himalayan Geology for providing necessary facilities and the reviewers for useful comments and valuable suggestions.

\section{References}

Auden J B 1934 The geology of the Krol Belt; Rec. Geol. Surv. India 67 357-454.

Banerjee D M and Narain M J 1976 Trace fossils in the Lower Tal Formation of Mussoorie and their environmental significance; J. Sedim. Petrol. 46 235-239.

Bhargava O N 1972 A reinterpretation of the Krol Belt; Him. Geol. 2 41-81.

Bhargava O N 1984 Trace fossils from the ?Cambrian Tal Group, Sirmur District, H.P. and proposed redefinition of the Tal; J. Palaentol. Soc. India 29 84-87.

Bhargava O N and Bassi U K 1988 Trace fossils from the Palaeozoic-Mesozoic sequence of Spiti-Kinnaur (Himachal Himalaya) with comments on palaeoenvironmental control on their frequency; J. Geol. Soc. India 32(3) 227-238.

Bhargava O N, Singh I, Hans S K and Bassi U K 1998 Early Cambrian trace and trilobite fossils from the Nigali Dhar Syncline (Sirmur District, Himachal Pradesh), lithostratigraphic correlation and fossil content of the Tal Group; Him. Geol. 19 89-108.

Crimes T P 1970 Trilobite tracks and other trace fossils from the Upper Cambrian of North Wales; Geol. J. 7 47-68.

Conway Morris S 1993 The fossil record and the early evolution of the Metazoa; Nature 361 219-225.

Conway Morris S 1998 The crucible of creation; Oxford University Press, Oxford, England, 242p.

Dawson J W 1873 Impressions and foot prints of aquatic animals and initiative markings on Carboniferous rocks. American J. Sci. 5(3) 16-24.

De C, Das D P and Raha P K 1994 Ichnostratigraphic and palaeoenvironmental significance of trace fossils from Tal Formation of Nigali Dhar Syncline, Sirmur District, Himachal Pradesh, India; Indian J. Geol. 66 77-90.

Desai B, Shukla R and Saklani R P 2010 Ichnology of the Early Cambrian Tal Group, Nigalidhar Syncline, Lesser Himalaya, India; Ichnos 17(4) 233-245.

Droser M L, Gehling J G and Jensen S 1999 When the worm turned; concordance of Early Cambrian ichnofabric and trace-fossil record in siliciclastic rocks of South Australia; Geology 27 625-628.

Erwin D, Valentine J and Jablonski D 1997 The origin of animal body plans; Am. Sci. 85 126-137.

Haldemann S S 1840 Supplement to number one of 'A monograph of the Limniades, and other fresh-water univalve shells of North America', containing descriptions of apparently new animals in different classes, and the names and characters of the subgenera in Paludina and Anculosa; J. Dobson Philadelphia, pp. 1-3.

Hall J 1847 Palaeontology of New York 1 C; Van Benthuysen, Albany, 338p.

Jensen S B, Saylor Z, Gehling J G and Germs G J B 2000 Complex trace fossils from the terminal Proterozoic of Namibia; Geology 28 143-146.

Kim J Y, Pickerill R K and Wilson R A 2000 Palaeophycus bolbitermilus isp. nov. from the Early Silurian Upsalquitch Formation of eastern Canada; Atl. Geol. 36 131-137.

Kumar G, Raina B K, Bhatt D K and Jangpangi B S 1983 Lower Cambrian body and trace-fossils from the Tal Formation, Garhwal Synform, Uttar Pradesh, India; J. Palaeontol. Soc. India 28 106-111.

Kumar S and Pandey S K 2010 Trace fossils from the Nagaur Sandstone, Marwar Supergroup, Dulmera area, Bikaner district, Rajasthan, India; J. Asian Earth Sci. 38 77-85.

Macleay W S 1839 Note on the Annelida; In: The Silurian System, Part II, Organic Remains (ed.) Murchison R I, J. Murray, London, pp. 699-701.

Medlicott H B 1864 On the geological structure and relation of the southern portion of the Himalayan ranges between the rivers Ganges and the Ravee; Geol. Surv. India Memoir 3(2) 1-212.

Metz R 1995 Ichnologic study of the Lockatong Formation (Late Triassic), Newark Basin, southeastern Pennsylvania; Ichnos 4 43-51.

Middlemiss C S 1887 Physical geology of west British Garhwal with notes on the route traverse through Jaunsar-Bawar and Tehri Garhwal; Rec. Geol. Surv. India 20 26-40.

Miller S A 1889 North American geology and paleontology for the use of amateurs, students and scientists; Western Methodist Book Concern, Cincinnati, 664p.

Nicholson H A 1873 Contribution to the study of the errant annelids of the Older Palaeozoic rocks; Proc. Roy. Soc. London 21 288-290.

Palij V M 1976 Remains of soft-bodied animals and trace fossils from deposits of Upper Precambrian and Lower Cambrian; Paleontology and Stratigraphy of Upper Precambrian and Lower Paleozoic of the south-west of Eastern-European Platform, Naukova dumka, Kiev, pp. 63-76 (in Russian).

Parcha S K 1998 Trace fossils from the Cambrian of Zanskar (Ladakh Himalaya) and their stratigraphic significance; J. Geol. Soc. India 51(5) 635-645.

Parcha S K and Pandey S 2011 Ichnofossils and their significance in the Cambrian successions of the Parahio Valley in the Spiti Basin, Tethys Himalaya, India; J. Asian Earth Sci. 11 1097-1116.

Parcha S K and Singh B P 2010 Stratigraphic significance of the Cambrian ichnofauna of the Zanskar region of Ladakh Himalaya, India; J. Geol. Soc. India 75 503-517.

Rai V 1987 Additional trace fossils from the Tal Formation (Early Cambrian) Mussoorie hills, Uttar Pradesh, India; J. Palaeontol. Soc. India 32 53-59.

Richter R 1973 Marken und Spuren aus allen Zeiten. I-Ii; Senckenbergiana Biologica 13 299-342.

Seilacher A 1955 Spuren und Fazies im Unterkambrium; In: Beiträge zur Kenntnis des Kambriums in der Salt Range (Pakistan) (eds) Schindewolf O H and Seilacher A, Akad. Wissensch. Lit. Mainz Math. Nat. Klasse Abhandl. 10 86-143.

Seilacher A 1967 Bathymetry of trace fossils; Marine Geol. 5 413-428.

Shah S K and Sudan C S 1983 Trace fossils from Cambrian of Kashmir and their stratigraphic significance; J. Geol. Soc. India 24(4) 194-202. 
Shanker R 1973 Stratigraphy and sedimentation of Tal Formation, Mussoorie Syncline, Uttar Pradesh; J. Palaeontol. Soc. India 16 1-15.

Shanker R 1975 Stratigraphic analysis of chert member, Lower Tal Formation in Dehradun and Tehri district, U.P.; Rec. Geol. Surv. India 106 54-74.

Shanker R 1989 The Mussoorie-Phosphate Basin, India; In: Phosphate Deposits of the World (eds) Notholt A J G, Sheldon R P and Davidson D E, Cambridge University Press, Cambridge, pp. 443-448.

Shanker R, Kumar G, Mathur V K and Joshi A 1993 Stratigraphy of the Blaini, Infrakrol, Krol and Tal succession, Krol belt, Lesser Himalaya; Indian J. Petrol. Geol. 2 99-136.

Singh I B and Rai V 1983 Fauna and biogenic structures in Krol-Tal succession (Vendian-Early Cambrian), Lesser
Himalaya: Their biostratigraphic and palaeoecological significance; J. Palaeontol. Soc. India 28 67-90.

Singh I B, Shukla V, Rai V and Kapoor P N 1984 Ichnogenus Skolithos in the Tal Formation of Mussoorie area; J. Geol. Soc. India 25(2) 102-107.

Tiwari M and Parcha S K 2006 Early Cambrian trace fossils from the Tal Formation of the Mussoorie Syncline, India; Curr. Sci. 90 113-119.

Tripathi C, Jangpangi B S, Bhatt D K, Kumar G and Raina B K 1984 Early Cambrian brachiopods from 'Upper Tal', Mussoorie Syncline, Dehradun District, Uttar Pradesh, India; Geophytology 14(2) 221-227.

Valdiya K S 1975 Lithology and age of Tal Formation in Garhwal and implication on stratigraphic scheme of Krol Belt in Kumaun Himalaya; J. Geol. Soc. India 169(2) 119-134. 